\title{
Developing English job interview skill using artificial intelligence technology
}

\author{
Dewanti Ratna Pertiwi*, Maria Asumpta Deny Kusumaningrum \\ Institut Teknologi Dirgantara Adisutjipto \\ Email: Correspondence : *dewantiratna@ stta.ac.id
}

Received February $1^{\text {st }}, 2021$; Revised February 18, 2021; Accepted February 22, 2021

\begin{abstract}
Vocational high schools (VHS) mainly prepare the students to engage in employment with a number of specific skills even though some students may continue to study in university/ college level. Various job vacancy advertisements require English skill in completing either the documents or interview. In competing the documents such as CV and cover letter, the students may adopt and adapt some templates even consult to the experts to get the best quality. However, in the interview, the students should perform themselves in live interaction. If the students are not well prepared, they may pass the documents selection but fail the interview step. Therefore, English job interview preparation is needed to equip the students ready in facing the job interview. Nowadays, artificial intelligence (AI) technology can help to improve the students' speaking skill including job interview. The use of AI becomes higher due to the advantages such as flexibility, accurateness, and direct feedback. This program applied AI technology to develop English job interview skill in of the students in SMK AAG Penerbangan Adisutjipto Yogyakarta. The result was the selected AI successfully improved the students' job interview skills indicated on the increased mark after applying the technology.

Keywords: job interview; artificial intelligence; technology
\end{abstract}

\section{INTRODUCTION}

A vocational high school (VHS) is a formal education after junior high school level that is designed to prepare the students ready to work with technical skills needed in completing tasks of a particular job. It is a great way to gain job-ready skills that prepare the students for a fulfilling career. Compared to senior high school students who are usually more academic, vocational high school students are more job-focused. Vocational education existed before the country achieved independence, and after reform. In 2008, the development of vocational training was altered. The government adjusted the ratio of senior high schools: vocational schools from 70 percent: 30 percent to 30 percent: 70 percent (Suharno, Pambudi, \& Harjanto, 2020). There are two types of VHS in terms of years accomplishment, namely three-year and four-year program (Soenarto, Amin, \& Kumaidi, 2017). They report that the four-year program is higher in quality due to the more attained skills and knowledge.

Preparing VHS students for job hunting is necessary to maximize the quality and quantity in labor market. To cope the tight competition in the labor market, VHS need to have collaborative boards such as teachers to train the skill and knowledge and liaison officers to enlarge partnerships with industrial companies [3]. Basically, there are four steps in job hunting namely research and preparation, writing an impressive $\mathrm{CV}$, writing effective cover letters, and preparing successful interview [4]. Among those four, successful interview is conducted in the last session and considered to be the most challenging. It effects the company through the interviewer judge the applicants to be accepted or rejected.

A job interview is the last decisive step in the series of job-hunting process. Some people think that there is no scarier than job interview because if the applicants are not well prepared, this short and live interaction can potentially create negative impression [5]. The documents submitted, CV and cover letter will be the source of interview matters for confirmation and clarification that finally reflect the applicants traits [6]. The job interview becomes more challenging conducted in English. Improved English communication skills will contribute not only to an improved social life, but also to better work prospects in the future [7]. Most interviewers perform interviews in English during work interviews. Interviewers make decisions easily and give first impressions great significance. Weak language skills can mean smaller opportunities to land a job.

Developing English job interview skills can be conducted in various techniques. Jailani \& Nurbatra (2019) used virtual reality (VR) for the students in business English class. The result indicated that the students were motivated and attracted using VR. The VR provides simulated object and artificial environment like the real-world version. In addition, self-access language learning (SALL) can be an alternative. A podcast-based 
media was applied for the job seeker recently graduated from English Department. The result showed enhancement from: (1) the changes according to the functional capacity, seen from the change of response style from descriptive to narrative; and (2) the changes according to the material, seen from the change of response content from daily routine to professional logical [9].

A community service in the form of developing English job interview skill is going to be carried out in SMK Penerbangan AAG Adisutjipto. It is an aviation vocational high school with airframe powerplant, electrical avionics, aircraft electricity, light vehicle engineering, and aircraft machining concentrations. The technique promoted artificial intelligence technology such as ELSA Speak application. It provides various facilities focusing on pronunciation development starting from sound, word, sentence, and conversation. Besides, the direct feedback is useful to reflect the user's pronunciation. Samad \& Aminullah (2019) investigated the students' perception in applying ELSA in the pronunciation class. The result indicated that the 12 students as the samples from English department were interested in using ELSA and thought that ELSA was very good. To support the interview skill, in its basic free package, ELSA provides some topics related to the field of aviation topic of self-introduction, pick your answer: interview, working for an airline, working in customer service, job interview, and business.

Based on the early investigation, the future career of the alumni of SMK Penerbangan AAG Adisutjipto are in international airline companies such as Garuda Maintenance Facility, Lion, etc. In terms of English job interview skills, sometimes the students are academically qualified but cannot pass the entrance test in English interview. The tight school programs also make the students do not have a special program for English job interview preparation. Therefore, this community service is expected to contribute in developing the students English job interview skill so that they can prepare their best efforts into the real job interview.

\section{METHODOLOGY}

Refer to the partner's problems, the community service was conducted in terms of action research following the scheme in cycles as described in [11]. The procedures of conducting the service were on Figure 1:

\section{Cycle 1}

\begin{tabular}{|c|c|c|c|c|}
\hline $\begin{array}{c}\text { Identifying } \\
\text { problem } \\
\text { (observation) }\end{array}$ & $\begin{array}{c}\text { Plan } \\
\text { (creating WA } \\
\text { group, 1st job } \\
\text { interview } \\
\text { assessment) }\end{array}$ & $\begin{array}{c}\text { 1st action } \\
\text { (introduction } \\
\text { of job } \\
\text { interview } \\
\text { skills and Al } \\
\text { by Webinar) }\end{array}$ & $\begin{array}{l}\text { Observation } \\
\text { (monitoring } \\
\text { the use of Al, } \\
\text { the } 2 \text { nd job } \\
\text { interview } \\
\text { assessment) }\end{array}$ & $\begin{array}{l}\text { Reflection } \\
\text { (comparing } \\
\text { the } 1 \text { st and } \\
\text { the } 2 \text { nd job } \\
\text { interview } \\
\text { assessment) }\end{array}$ \\
\hline
\end{tabular}

\section{Cycle 2}

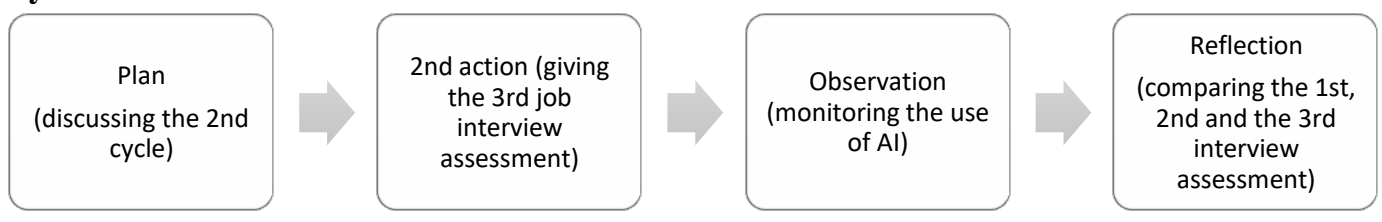

Figure 1. Community Service Procedures

\section{Result and Discussion}

The service was divided into 2 cycles. Cycle 1 was used to observe the beginning condition, introduce the artificial intelligent, and conduct the early assessments. After getting the improvement from Cycle 1, it was convinced by Cycle 2 concentrating on the other assessments.

\subsection{Cycle 1}

\subsubsection{Identifying problem}

To identify the problems, an observation was done by discussing how the students' condition related to job interview skills to the vice headmaster of academic affairs and the English teachers. The vice headmaster reported that some selected students have joined an English community to have develop their English skills and to prepare if someday there is an agenda that requires English competence such as a competition. It is followed by the students from all the departments and grades. In general, the students in this community have better English competence. 
The English teachers supported that there is no mapping to describe the students' job interview skills. However, few students in this community achieved more than 800 Score in the Advanced TOEIC prediction test. The teachers predicted that the job interview skills are likely equal. They added that there is no special activity to prepare the students facing job interview but some students initiated to consult their job interview preparation in case they will hunt for a job.

\subsubsection{Plan}

A follow up step was done to organize more effective communication. A WhatsApp room was created to accommodate the next steps. This room was attended by the students, the English teachers and the community service lecturer to discuss the first action, webinar. The lecturer also posted the $1^{\text {st }}$ assessment by asking the students to record their voice about their responses for some most common interview questions and submit online. The result was assessed based on an adapted job interview rubric taken from https://s3.studylib.net/store/data/025345353_1-d8e1095cf56a20ff8167acc621e03579.png as follows

Table 1. Interview rubric.

\begin{tabular}{|c|c|c|c|c|c|}
\hline Score & Fluency & $\begin{array}{l}\text { Pronunciation } \\
\text { and Accent }\end{array}$ & Vocabulary & Grammar & Details \\
\hline 5 & $\begin{array}{l}\text { Smooth and } \\
\text { fluid speech; } \\
\text { few to no } \\
\text { hesitations; no } \\
\text { attempts to } \\
\text { search for } \\
\text { words; volume } \\
\text { is excellent. }\end{array}$ & $\begin{array}{l}\text { Pronunciation } \\
\text { excellent; good } \\
\text { effort at accent }\end{array}$ & $\begin{array}{l}\text { Excellent } \\
\text { control of } \\
\text { language } \\
\text { features; a } \\
\text { wide range of } \\
\text { well-chosen } \\
\text { vocabulary }\end{array}$ & $\begin{array}{l}\text { Accuracy \& } \\
\text { variety of } \\
\text { grammatical } \\
\text { structures }\end{array}$ & $\begin{array}{l}\text { Excellent } \\
\text { level of } \\
\text { description; } \\
\text { additional } \\
\text { details } \\
\text { beyond the } \\
\text { required }\end{array}$ \\
\hline 4 & $\begin{array}{l}\text { Smooth and } \\
\text { fluid speech; } \\
\text { few hesitations; } \\
\text { a slight search } \\
\text { for words; } \\
\text { inaudible word } \\
\text { or two }\end{array}$ & $\begin{array}{l}\text { Pronunciation is } \\
\text { good; good } \\
\text { effort at accent }\end{array}$ & $\begin{array}{l}\text { Good } \\
\text { language } \\
\text { control; good } \\
\text { range of } \\
\text { relatively } \\
\text { wellochosen } \\
\text { vocabulary }\end{array}$ & $\begin{array}{l}\text { Some errors in } \\
\text { Grammatical } \\
\text { structures } \\
\text { possibly } \\
\text { caused by } \\
\text { attempt to } \\
\text { include a } \\
\text { variety }\end{array}$ & $\begin{array}{l}\text { Good level of } \\
\text { description; } \\
\text { all required } \\
\text { information } \\
\text { included }\end{array}$ \\
\hline 3 & $\begin{array}{l}\text { Speech is } \\
\text { relatively } \\
\text { smooth; some } \\
\text { hesitation and } \\
\text { unevenness } \\
\text { caused by } \\
\text { rephrasing and } \\
\text { searching for } \\
\text { words; volume } \\
\text { wavers }\end{array}$ & $\begin{array}{l}\text { Pronunciation is } \\
\text { good; some } \\
\text { effort as accent, } \\
\text { but is definitely } \\
\text { non-native }\end{array}$ & $\begin{array}{l}\text { Adequate } \\
\text { language } \\
\text { control; } \\
\text { vocabulary } \\
\text { range is } \\
\text { lacking }\end{array}$ & $\begin{array}{l}\text { Frequent } \\
\text { grammatical } \\
\text { errors that do } \\
\text { not obscure } \\
\text { meaning; little } \\
\text { variety in } \\
\text { structures }\end{array}$ & $\begin{array}{l}\text { Adequate } \\
\text { description; } \\
\text { some } \\
\text { additional } \\
\text { details should } \\
\text { be provided }\end{array}$ \\
\hline 2 & $\begin{array}{l}\text { Speech is } \\
\text { frequently } \\
\text { hesitant with } \\
\text { some sentences } \\
\text { left } \\
\text { uncompleted; } \\
\text { volume very } \\
\text { soft }\end{array}$ & $\begin{array}{l}\text { Pronunciation is } \\
\text { okay; No effort } \\
\text { towards a native } \\
\text { accent }\end{array}$ & $\begin{array}{l}\text { Weak } \\
\text { language } \\
\text { control; basic } \\
\text { vocabulary } \\
\text { choice with } \\
\text { some words } \\
\text { clearly } \\
\text { lacking }\end{array}$ & $\begin{array}{l}\text { Frequent } \\
\text { grammatical } \\
\text { errors even in } \\
\text { simple } \\
\text { structures that } \\
\text { at times } \\
\text { obscure } \\
\text { meaning }\end{array}$ & $\begin{array}{l}\text { Description } \\
\text { lacks some } \\
\text { critical } \\
\text { details that } \\
\text { make it } \\
\text { difficult for } \\
\text { the listener to } \\
\text { understand }\end{array}$ \\
\hline 1 & $\begin{array}{l}\text { Speech is slow, } \\
\text { hesitant \& } \\
\text { strained except } \\
\text { for short } \\
\text { memorized } \\
\text { phrases; }\end{array}$ & $\begin{array}{l}\text { Pronunciation is } \\
\text { lacking and } \\
\text { hard to } \\
\text { understand; No } \\
\text { effort towards a } \\
\text { native accent }\end{array}$ & $\begin{array}{l}\text { Weak } \\
\text { language } \\
\text { control; } \\
\text { vocabulary } \\
\text { that is used } \\
\text { does not } \\
\text { match the task }\end{array}$ & $\begin{array}{l}\text { Frequent } \\
\text { grammatical } \\
\text { errors even in } \\
\text { simple } \\
\text { structures; } \\
\text { meaning is } \\
\text { obscured }\end{array}$ & $\begin{array}{l}\text { Description } \\
\text { is so lacking } \\
\text { that the } \\
\text { listener } \\
\text { cannot } \\
\text { understand }\end{array}$ \\
\hline
\end{tabular}


The average mark for the $1^{\text {st }}$ assessment was described in the following figure.

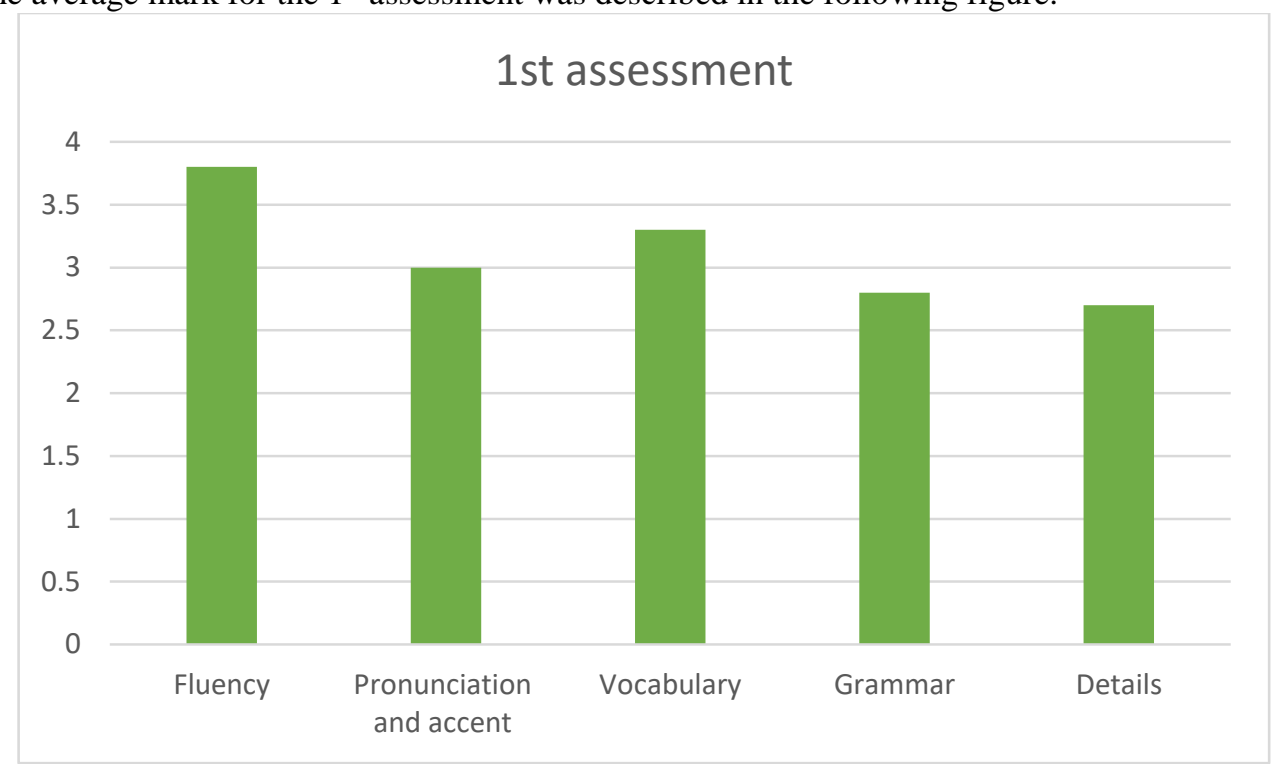

Figure 2. $1^{\text {st }}$ assessment

\subsubsection{Action}

The third step was the action to improve the job interview skill. Since it was still in the Covid-19 pandemic, the action was conducted in webinar. The purpose was to introduce the job interview skills and artificial intelligent technology that was possibly used. The webinar was recorded and uploaded in YouTube with this link https://youtu.be/47xUirPVdCc.

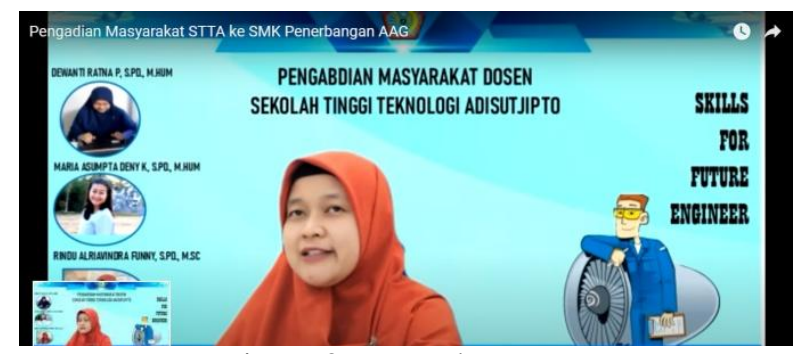

Figure 3. YouTube screen

One of the possible technologies is ELSA Speak. The good facilities are Topic that provides the users to select certain theme and Mixed Skills that train the users to jump into more detail questions, record the users' voice, and give feedback with range score between 0-100 and correction in green (correct), yellow (rather correct) and red (need improvement). In this community service, the students selected 1) Topic, 2) Pick your answers: Interview, 3) Lesson three, 4) Start. The application gave questions and clues so that the students could choose the best alternative choice and record the voice. After a few seconds, a feedback in score ranged 0-100 and indicated colors appeared. Green means excellent, yellow means almost excellent, and red means need improvement. The students were allowed to try over and over again until the highest score. 

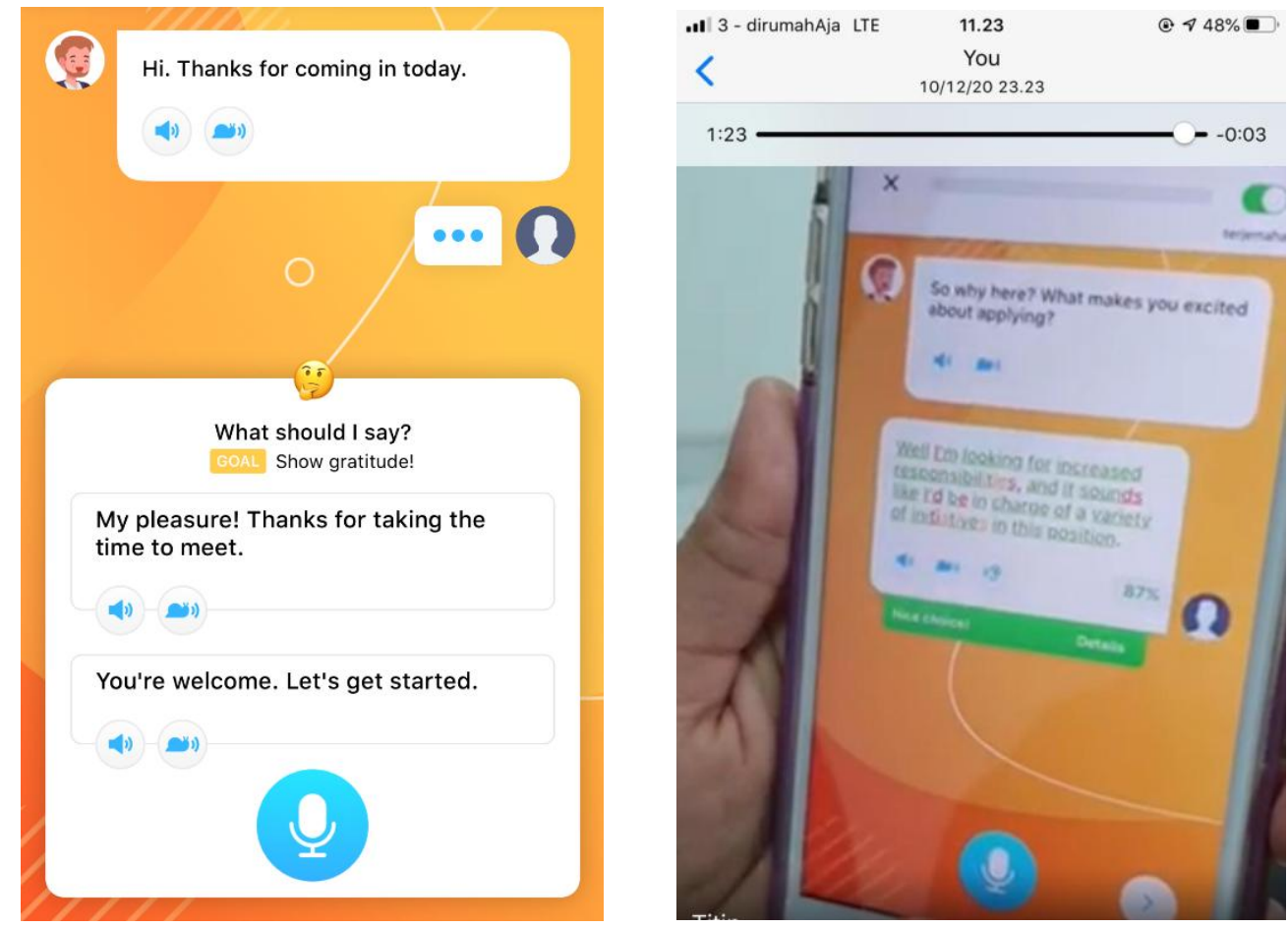

Figure 4. Feedback

\subsubsection{Observation}

Monitoring the use of artificial intelligent technology was done after the webinar by communicating it in the WhatsApp room. To check the improvement, the $2^{\text {nd }}$ assessment was delivered. The result was there was a little higher achievement as described in the following chart.

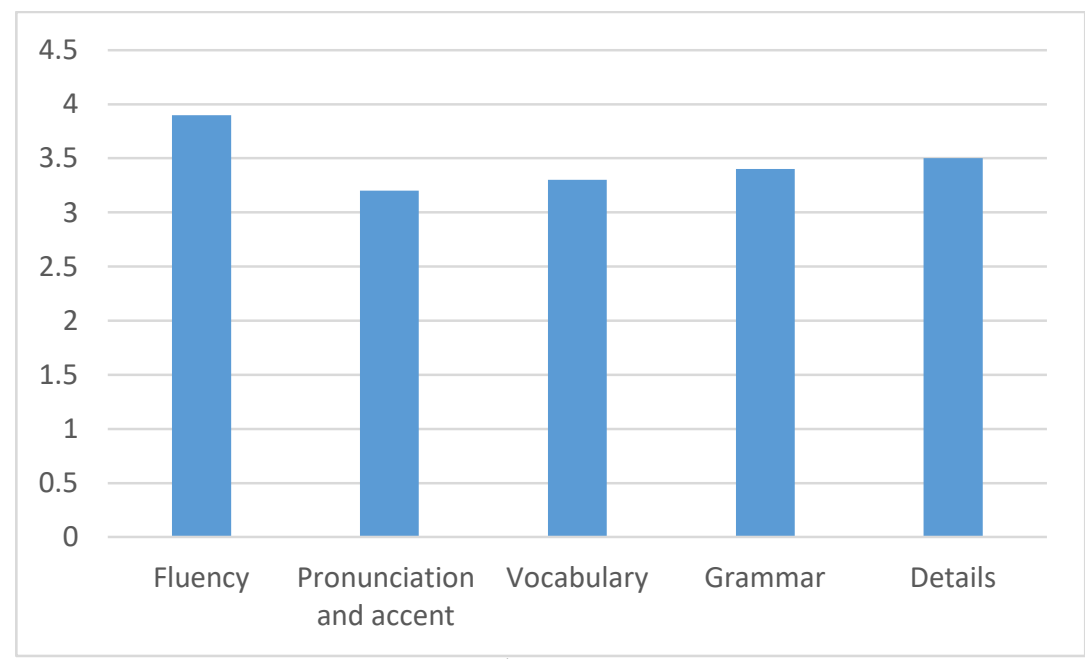

Figure 5. $2^{\text {nd }}$ assessment

\subsubsection{Reflection}

Comparing the $1^{\text {st }}$ and the $2^{\text {nd }}$ job interview assessment was necessary to see how much improvement occurred as presented in Figure 6. The fluency increased a little with 0,1 average mark. The pronunciation increased higher than the fluency with 0,2 . Unfortunately, the vocabulary mark remained the same. The grammar increased 0,6 while the details component achieved the highest improvement with 0,8 average mark. 


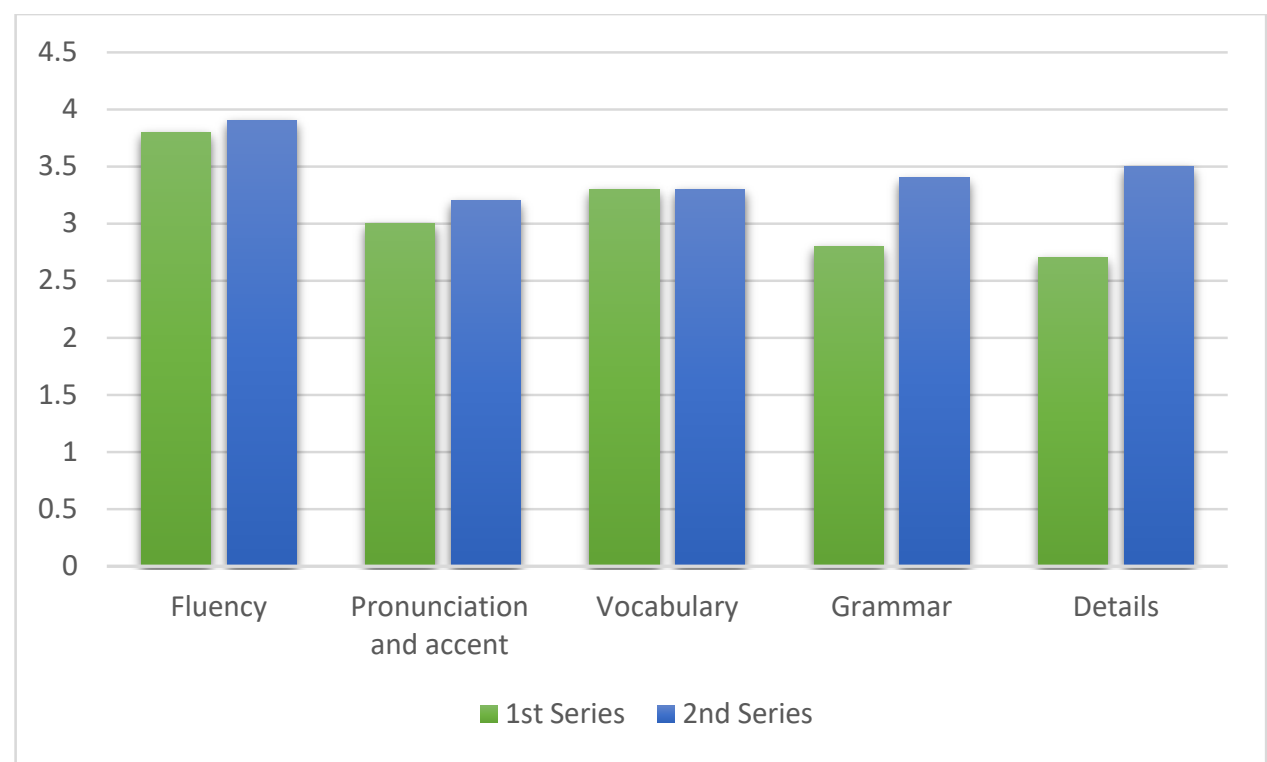

Figure 6. Mark comparison between $1^{\text {st }}$ and $2^{\text {nd }}$ assessment

\subsection{Cycle 2}

3.2.1 Plan

In an action research study, the result of the first cycle should be convinced by the following cycles for at least once. To begin Cycle 2, planning was conducted by discussing the next action. In this case, sharing materials was again carried out about other tips in delivering a job interview while drilling the interview skills using artificial intelligence technology. After that, the $3^{\text {rd }}$ assessment was done followed by reflection for the whole assessments.

\subsubsection{Action}

The sharing materials was delivered in WhatsApp room. Questions and answers session was closer, more natural, and more intensive in this $2^{\text {nd }}$ action. Some tips were shared how to handle job interview questions designed using Canva application that is more interesting as described in Figure 7. Some participants also clarified what were the proper answers in the $1^{\text {st }}$ and $2^{\text {nd }}$ assessment and shared some problems that were found in using AI technology. Here, the was also interview about the participants' perception in using AI technology. They felt AI was interesting, flexible, helpful in improving their job interview skills.

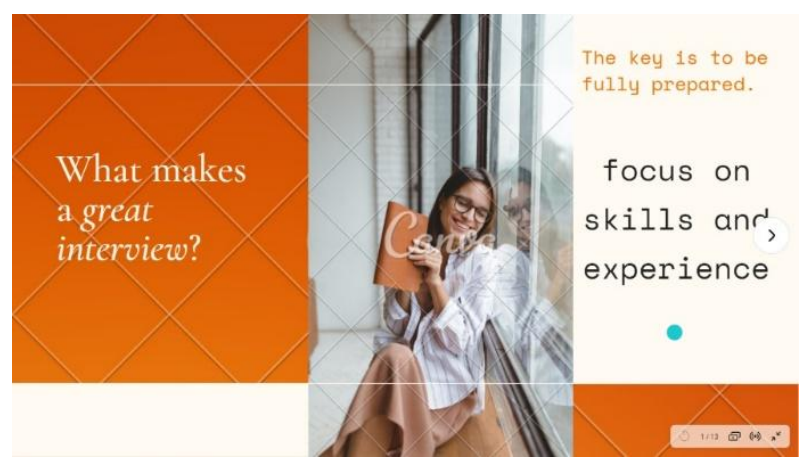

Figure $7.2^{\text {nd }}$ action material

\subsubsection{Observation}

Observing the following improvement was carried out in the $3^{\text {rd }}$ assessment. Details got the highest mark among the five components. The participants developed their ability to describe the supporting information in this details component by elaborating facts of skills and experience that they had. In the previous assessment, the participants tended to describe the short explanation without any details of skills and experience. 


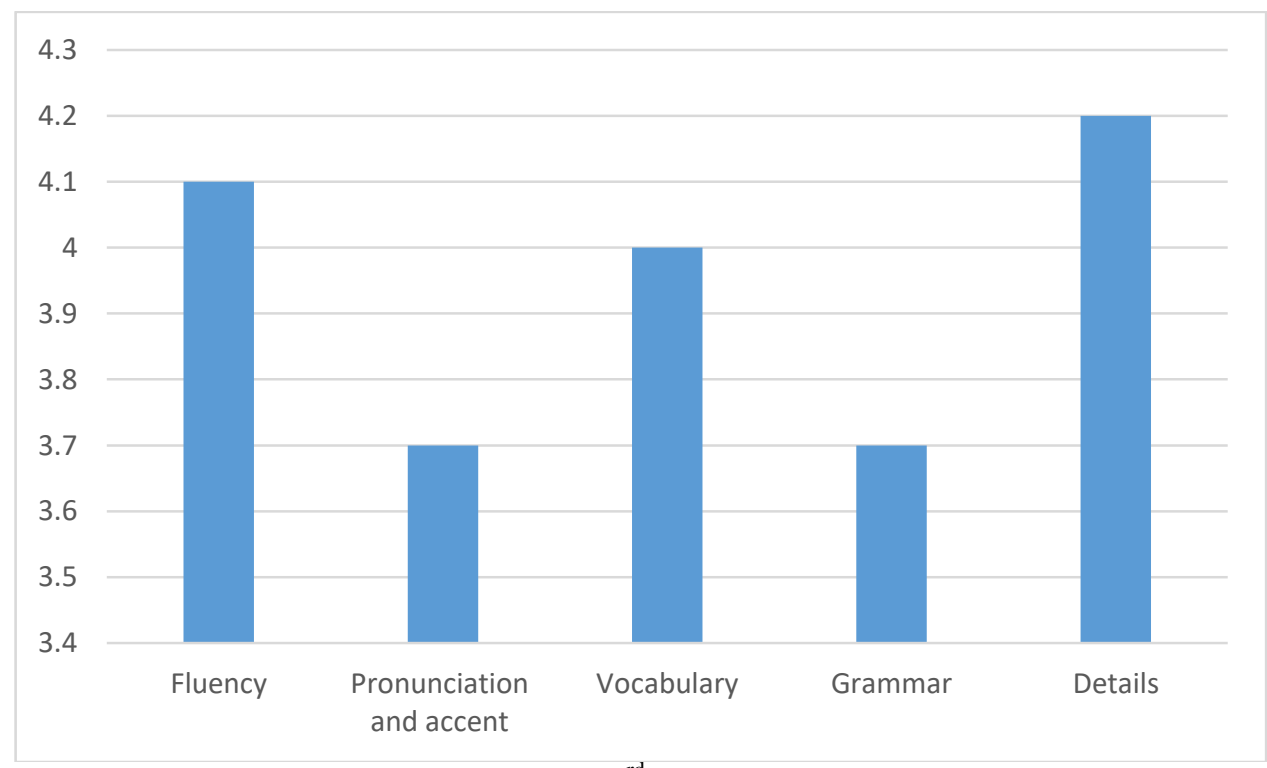

Figure $8.3^{\text {rd }}$ assessment

\subsubsection{Reflection}

Reflecting the three assessments, the five interview rubrics increased the achievement from the first, to the second, and to the third as described in Figure .... The fluency raised fairly compared to the pronunciation that raised a little from the first to the second and raised higher form the second to the third. Meanwhile, the vocabulary stayed the same in the first and the second but increased a lot from the second to the third. On the other hand, grammar raised a lot form the first to the second and increased a little from the second to the third. The last, details component raised consistently a lot from the first to the second and from the second to the third.

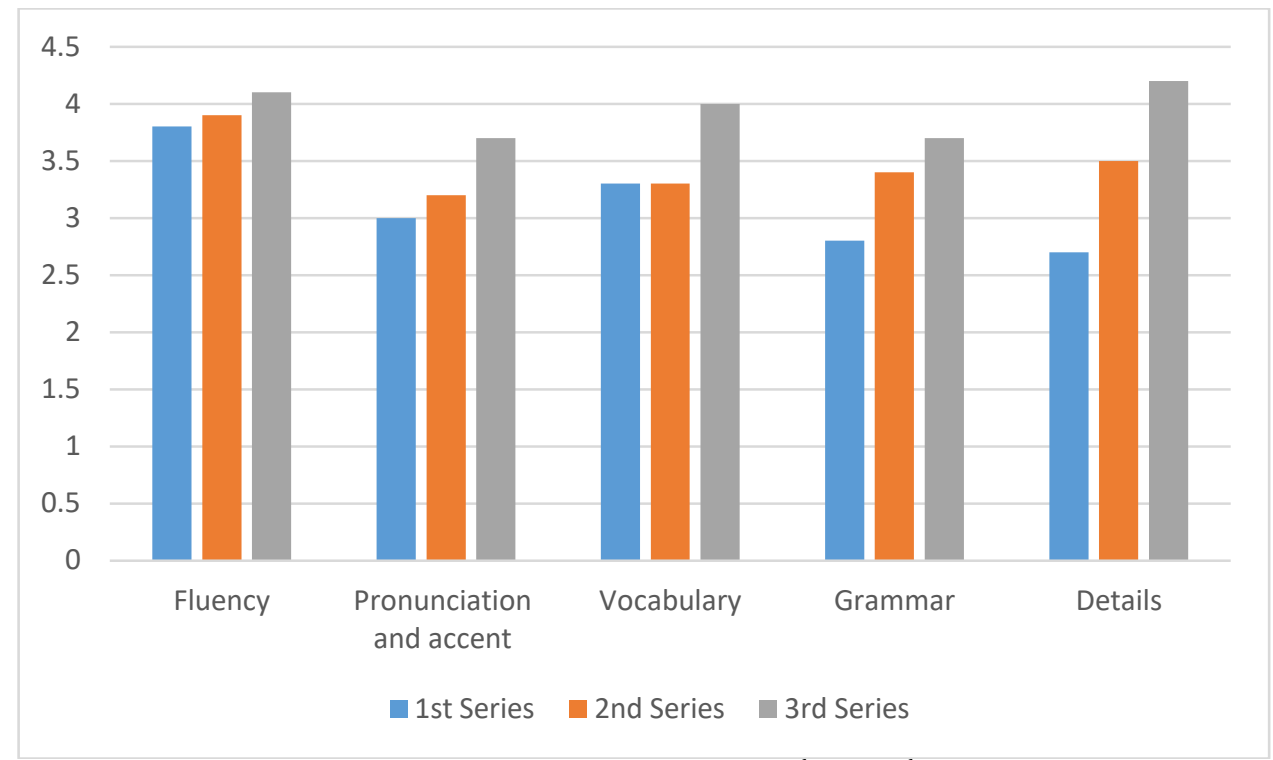

Figure 9. Mark comparison between $1^{\text {st, }} 2^{\text {nd, }}$ and $3^{\text {rd }}$ assessment

\section{Conclusion}

The research concluded that the artificial intelligence (AI) technology was able to improve the participants' job interview skills. The students' responses also the students' performances indicated positive improvement on the job interview skills. The AI allowed the students to use and develop the interview skills autonomously and flexibly got the feedback indicating their achievement. For the following research, it is recommended to improve other language cases and involve more technologies. 


\section{REFERENCES}

[1] B. Suharno; Pambudi, N. A.; Harjanto, "Vocational education in Indonesia: History, development, opportunities, and challenges," Child. Youth Serv. Rev., vol. 115, no. May, p. 105092, 2020.

[2] M. M. . K. Soenarto; Amin, “An evaluation of vocational high schools in Indonesia: A,” vol. 3, no. 2, pp. 106$113,2017$.

[3] I. M. Hambali, "Examining The Relevance of Indonesian Vocational High School Career Outcomes to The Labor Market IM Hambali 1," vol. 10, no. 1, pp. 133-155, 2019.

[4] C. . Downes, Cambridge English for Job-hunting. Cambridge: Cambridge University Press, 2008.

[5] M. Otlowski, "Preparing University EFL Students for Job Interviews in English : A Task-Based Approach," no. February, pp. 1-30, 2008.

[6] L. Lundmann, “A QUALITATIVE STUDY OF JOB INTERVIEWERS ' IMPLICIT PERSON THEORIES,” $J$. Integr. Soc. Sci., vol. 7, no. 1, pp. 1-32, 2017.

[7] P. Pandey, M.; Pandey, "Better English for Better Employment Opportunities," Int. J. Multidiscip. Approaches Stud., vol. Volume 1, no. August, pp. 96-103, 2014.

[8] M. K. . Jailani and L. H. Nurbatra, "Virtual Reality System for Job Interview Application: a Development Research," A J. Cult. English Lang. Teach. Lit. Linguist., vol. 6, no. 1, p. 31, 2019.

[9] A. . Soerjowardhana and R. A. Nugroho, "Developing English Job Interview Skill by Self-Access Language Learning through Audio Podcast-Based Learning Media," Celt A J. Cult. English Lang. Teach. Lit., vol. 17, no. 2, p. 179, 2017.

[10] I. S. . Samad and A. Aminullah, "Applying ELSA Speak Software in the Pronunciation Class: Students' Perception," Edumaspul - J. Pendidik., vol. 3, no. 1, pp. 56-63, 2019.

[11] A. Phakiri, P. De Costa, L. Plonsky, and S. Starfield, Eds., The Palgrave Handbook of Applied Linguistics Research Methodology. Macmillan: Palgrave, 2018. 